\title{
Production of Functional Kampong Chicken Meat with Low Cholesterol, High Antioxidant, and Unsaturated Fatty Acids Fed Noni (Morinda citrifolia) Leaf Shoot Meal
}

\author{
T. M. Wardiny ${ }^{\mathrm{a} *}$, Sumiati $^{\mathrm{b}}$, Y. Retnani $^{\mathrm{b}}$, \& A. Setiyono ${ }^{\mathrm{c}}$ \\ aAgribusiness Study Program, Faculty of Science and Technology, Universitas Terbuka \\ Jalan Cabe Raya, Pondok Cabe, Jakarta, Indonesia \\ ${ }^{b}$ Department of Nutrition and Feed Technology, Faculty of Animal Science, IPB University \\ (Bogor Agricultural University) \\ 'Department of Veterinary Clinic, Reproduction, and Pathology, Faculty of Veterinary, IPB University \\ (Bogor Agricultural University) \\ Jalan Agatis, Kampus IPB Darmaga Bogor 16680, Indonesia \\ *Corresponding author: tuty@ecampus.ut.ac.id \\ (Received 04-05-2019; Revised 18-06-2019; Accepted 12-08-2019)
}

\begin{abstract}
The objective of this study was to evaluate the effect of noni (Morinda citrifolia) leaf shoot meal (NLSM) supplementation in the ration on the performances of kampong chickens as well as lipid, malondialdehyde (MDA), and fatty acid contents of meats. Two hundred and forty kampong chickens of 4 weeks old were reared until 12 weeks old. The diet treatments were R0: 0\% NLSM (control), R1: 0.5\% NLSM, R2: 1\% NLSM, R3: 1.5\% NLSM, R4: 2\% NLSM, and R5: 2.5\% NLSM. A completely randomized design (CRD) was used with six treatments and four replications with ten kampong chickens per replicate. The data were analyzed using ANOVA and if there were significant different, the data were further analyzed using Duncan's Multiple Range Test. The variables measured were performances of kampong chickens as well as lipid, MDA, and fatty acid contents of meat. The result showed that cholesterol and LDL contents of meat were significantly reduced by feeding NLSM. Performance and HDL contents of meat were not significantly different for all diet treatments. In addition, feeding kampong chickens with ration supplemented with NLSM could reduce MDA, saturated fatty acids and increase unsaturated fatty acids contents of meat. It is concluded that $2.5 \%$ NLSM can be used to improve meat quality of kampong chicken as functional meat.
\end{abstract}

Keywords: cholesterol; fatty acid; MDA; Morinda citrifolia; kampong chicken

\section{INTRODUCTION}

Increased public awareness of healthy living makes people choose foods having good nutritional compositions and physiological functions for the body. Kampong chicken meat is one of the products that is recognized to have those criteria. This condition makes the chicken farms have a great opportunity in Indonesia to produce good and healthy food. Another reason for the cultivation of kampong chicken is its resistance to several diseases and high selling price. In contrast, some of these advantages are not followed by high productivity because the growth rates of kampong chickens are lower than those of broiler chickens. It takes longer time for kampong chickens to achieve the same bodyweight as broiler. Some of the causes are genetic, maintenance, feed, and health factors. There was a new breed of kampong chicken in the market known as Superior Kampong (KUB) for egg production, even though it has also been utilized for meat production. The growth of KUB chicken for meat was more than one $\mathrm{kg}$ at the age of 10 to 12 weeks. This bodyweight can be obtained by using a balanced diet of protein and energy by paying attention to the growth phase of the chicken.

However, some people still consider that consuming meat can increase the risk of cardiovascular disease. This consideration is related to the facts that saturated fatty acids in meat can increase the concentrations of low-density lipoprotein (LDL) cholesterol (Hoenselaar, 2012). This fact makes a great challenge for the freerange chicken farms to produce functional meat needed by the community. Cholesterol level in poultry meat is one of the most essential qualitative characteristics for consumers and its concentration can be modified efficiently through feed formulation (Dhama et al., 2015). One of solutions that have been found by the researchers is to use herbs in the feed mixture. Noni (Morinda citrifolia) is one of the herbal plants used in animal feed. Based on the phytochemical analysis, noni leaf shoots contain active ingredients of flavonoids, phenol hydroquinone, steroids, triterpenoids, tannins, and saponins. Flavonoids, tannins, and saponins have the potential as 
sources of natural antioxidants. Ferretti (2010) reports that dietary consumption of fruits and vegetables is associated with a lower incidence of degenerative diseases such as cardiovascular disease and certain types of cancers because bioactive phenolic compounds contained in fruits and vegetables have been thought to contribute to the protective role. Phenolic compounds are recognized as a class of antioxidant agents which act as free radical terminators (Doss et al., 2010). Natural antioxidants can be obtained from plant extracts and fruits that can improve meat shelf-life and quality, mainly by retarding lipid oxidation and microbial growth (Velasco \& Williams, 2011; Phan-Thi \& Wache, 2014). Besides, xantophyll and $\beta$-carotene are the sources of antioxidant that can increase the yolk pigmentation and improve the health of chicken (Lee et al, 2010). Beta carotene serves to protect cell damage, enhance immunity, and as a precursor of vitamin A (Phan-Thi et al., 2016). Some research on the use of noni leaves has been done in broilers. However, research using noni leaf shoots on KUB chicken as a source of antioxidants has never been conducted.

The purpose of this study was to evaluate the effect of noni (Morinda citrifolia) leaf shoot meal (NLSM) on the performances of kampong chickens, as well as lipid, malondialdehyde (MDA), and fatty acid contents of meat.

\section{MATERIALS AND METHODS}

\section{Noni Powder Preparation}

The noni leaf shoots having 3-4 young leaves were picked. Then the selected noni leaf shoots were thinly sliced and aerated for one day. After air drying, the materials were dried in the oven for one day at $55^{\circ} \mathrm{C}$. The dried noni leaf shoots were ground to powder.

\section{Animal and Diets}

The experiment was conducted in a completely randomized design (CRD) with six treatments and four replications with ten kampong chickens in each replicate. The chickens were placed in cages of $1.5 \times 1.5$ $\mathrm{m}$ in size. Two hundred and forty kampong chickens of four weeks old were reared until twelve weeks old. The diet treatments were R0: 0\% NLSM (control), R1: 0.5\% NLSM, R2: 1\% NLSM, R3: 1.5\% NLSM, R4: 2\% NLSM, and R5: $2.5 \%$ NLSM. The feed components were rice bran, corn, meat-bone meal, soybean meal, noni leaf shoot meal, oil, $\mathrm{CaCO}_{3^{\prime}}$ premix, DCP, $\mathrm{NaCl}$, Lysine, and DL-methionine. The diets were formulated isocalori and isoprotein with $17 \%$ protein and $2800 \mathrm{kcal} \mathrm{kg}^{-1}$ according to the recommendation of Leeson \& Summers (2008). The detailed diets compositions are presented in Table

Table 1. Composition of the experimental diets and calculated nutrient contents

\begin{tabular}{|c|c|c|c|c|c|c|}
\hline \multirow{2}{*}{ Ingredients } & \multicolumn{6}{|c|}{ Treatments } \\
\hline & R0 & R1 & $\mathrm{R} 2$ & R3 & $\mathrm{R} 4$ & R5 \\
\hline Yellow corn (\%) & 56.00 & 56.00 & 56.00 & 56.00 & 56.00 & 56.00 \\
\hline Rice bran (\%) & 17.25 & 17.00 & 16.75 & 16.50 & 16.00 & 15.75 \\
\hline Soybean meal (\%) & 17.00 & 16.50 & 16.00 & 15.50 & 15.00 & 14.5 \\
\hline Meat bone meal (\%) & 5.00 & 5.25 & 5.50 & 5.75 & 6.25 & 6.5 \\
\hline Noni leaf shoot meal (\%) & & 0.50 & 1.00 & 1.50 & 2.00 & 2.50 \\
\hline Oil (\%) & 1.30 & 1.30 & 1.30 & 1.30 & 1.30 & 1.30 \\
\hline $\mathrm{DCP}(\%)$ & 1.17 & 1.17 & 1.17 & 1.26 & 1.26 & 1.26 \\
\hline $\mathrm{CaCO} 3(\%)$ & 1.10 & 1.10 & 1.10 & 1.00 & 1.00 & 1.00 \\
\hline $\mathrm{NaCl}(\%)$ & 0.20 & 0.20 & 0.20 & 0.20 & 0.20 & 0.20 \\
\hline Premix (\%) & 0.50 & 0.50 & 0.50 & 0.50 & 0.50 & 0.50 \\
\hline L-Lysine (\%) & 0.35 & 0.35 & 0.35 & 0.35 & 0.35 & 0.35 \\
\hline DL-Methionine (\%) & 0.13 & 0.13 & 0.13 & 0.14 & 0.14 & 0.14 \\
\hline \multicolumn{7}{|l|}{ Calculated nutrient content: } \\
\hline $\operatorname{ME}\left(\mathrm{kcal} \mathrm{kg}^{-1}\right)$ & 2838.25 & 2839.50 & 2840.75 & 2842.01 & 2844.76 & 2846.01 \\
\hline Crude protein $(\%)$ & 17.66 & 17.62 & 17.57 & 17.53 & 17.58 & 17.53 \\
\hline Fiber $(\%)$ & 4.95 & 5.01 & 5.08 & 5.14 & 5.22 & 5.28 \\
\hline Fat $(\%)$ & 4.11 & 4.12 & 4.13 & 4.14 & 4.13 & 4.14 \\
\hline Lysine (\%) & 1.23 & 1.23 & 1.22 & 1.22 & 1.22 & 1.21 \\
\hline Methionine (\%) & 0.45 & 0.45 & 0.45 & 0.45 & 0.45 & 0.45 \\
\hline Cystine (\%) & 0.25 & 0.24 & 0.24 & 0.24 & 0.24 & 0.23 \\
\hline Methionine + Cystine (\%) & 0.70 & 0.69 & 0.68 & 0.69 & 0.69 & 0.68 \\
\hline Calcium (\%) & 1.13 & 1.77 & 1.78 & 1.78 & 1.80 & 1.81 \\
\hline Phosphor (\%) & 0.49 & 0.49 & 0.49 & 0.51 & 0.50 & 0.50 \\
\hline
\end{tabular}

Note: *Per kg vitamin premix contains: Vitamin A (10.000.000 IU), Vitamin D3 (2.000.000 IU), Vitamin E (20.000 IU), Vitamin K3 (750mg), Vitamin B1 (500mg), Vitamin B2 (3.500mg), Vitamin B6 (3.000mg) Vitamin B12 (12mg), Niacin (25.000mg), Pantothenic Acid (10.000mg), Folic Acid (500mg), Biotin (50mg), Antioxidant (25.000 mg), Carrier (+mg).

$\mathrm{R} 0=$ control ration; $\mathrm{R} 1=0.5 \% \mathrm{NLSM}$ in ration; $\mathrm{R} 2=1 \% \mathrm{NLSM}$ in ration; $\mathrm{R} 3=1.5 \% \mathrm{NLSM}$ in ration; $\mathrm{R} 4=2 \% \mathrm{NLSM}$ in ration, and $\mathrm{R} 5=2.5 \% \mathrm{NLSM}$ in ration. 
1. During the experiment, feed and water were provided ad libitum. The parameters measured were performances (feed consumption, body weight gain, and feed conversion), and meat quality components (lipid, malondialdehyde (MDA), and fatty acid contents). At the end of the study, 48 kampong chickens were slaughtered by cutting their jugular veins. Meats from right thigh parts were isolated and mashed to analyze its cholesterol, MDA, and fatty acid contents. Meat cholesterol contents were measured according to Liebermann-Burchard method by using spectrophotometer (Burke. et al., 1974). Meat fat contents were measured according the Direct Extraction Method (National Standardization Agency of Indonesia, 1992). Malondialdehyde concentrations were measured based on the method of Rice-Evans et al. (1991). Meat fatty acid contents were measured by using the methylation method (AOAC, 1984).

\section{Laboratory Analysis}

Total meat cholesterol. Total meat cholesterol in the samples was measured based on the method of Burke et al. (1974). To determine total meat cholesterol levels, fine-dry meat samples were analyzed using the CHODPAP method, which used enzymatic colorimeter kits for cholesterol with lipid clearing factors (LCF). The reagents used were phosphate buffer ( $\mathrm{pH}$ 6.5), 4-aminophenazone, phenol, peroxidase, cholesterolesterase, cholesteroloxidase, and sodium azide as well as cholesterol as a standard. Preparation of samples was carried out by weighing as much as $1 \mathrm{~g}$ of meat. The meat sample was put into a tube and added with $5 \mathrm{~mL}$ of diethyl ether (extraction I). The mixture was stirred and left \pm 30 minutes in the freezer $\left(-20^{\circ} \mathrm{C}\right)$. The solution was poured into the tube (extraction I). The precipitate was extracted by adding $5 \mathrm{~mL}$ of diethyl ether then stirred and put in the freezer $\left(-20^{\circ} \mathrm{C}\right)$ for 30 minutes (extraction II). The results of extraction I were combined with the results of extraction II and the mixed extract was left for 48 hours. The extracted results were added with $1 \mathrm{~mL}$ of phosphate saline buffer (PBS) and centrifuged at $2500 \mathrm{rpm}$ for 10 minutes. The supernatant was transferred to a spectrophotometer tube. The absorbance readings were conducted at the wavelength of $\lambda \mathrm{nm}$ with a standard concentration of $200 \mathrm{mg} \mathrm{dL}^{-1}$. Cholesterol concentrations were calculated by using the following formula: Cholesterol $\left(\mathrm{mg} \mathrm{dL}^{-1}\right)=200 \times$ (Fresh weight of sample/ Fresh weight of standard)

Meat HDL cholesterol. The preparation of samples was carried out by weighing as much as $1 \mathrm{~g}$ of meat. The meat sample was put into a tube and added with $5 \mathrm{~mL}$ of diethyl ether (extraction I). The mixture was stirred and left \pm 30 minutes in the freezer $\left(-20^{\circ} \mathrm{C}\right)$. The solution was poured into the tube (extraction I). The precipitate was extracted by adding $5 \mathrm{~mL}$ of diethyl ether, then stirred and put in the freezer $\left(-20^{\circ} \mathrm{C}\right)$ for 30 minutes (extraction II). The results of extraction I were combined with the results of extraction II and the mixed extract was left for 48 hours. The extracted results were added with $1 \mathrm{~mL}$ of phosphate saline buffer (PBS) and centrifuged at $2500 \mathrm{rpm}$ for 10 minutes. Separate the super- natant as much as $0.01 \mathrm{mg}$, then add $1 \mathrm{~mL}$ cholesterol reagent solution to the supernatant. The clear supernatant was separated and tested for HDL cholesterol levels using the CHOD-PAP method as in the measurement of total cholesterol. After that, the absorbance readings are carried out at a wavelength $(\lambda)$ of $500 \mathrm{~nm}$ with a standard concentration of $200 \mathrm{mg}$ dL-1. HDL cholesterol concentrations were calculated by using the following formula:

HDL cholesterol $\left(\mathrm{mg} \mathrm{dL}^{-1}\right)=200 \times$ (Abs. of sample/Abs. of standard)

Meat LDL cholesterol. To determine LDL cholesterol levels, the total cholesterol, HDL cholesterol, and triglyceride levels were calculated using the Friedwald formula:

LDL cholesterol= Total cholesterol - HDL cholesterol - (Triglyceride/5)

Meat fat. Meat fat content was measured using the Direct Extraction Method (National Standardization Agency of Indonesia,1992). Meat sample at the weight of 1-2 gram was put in a piece of paper sleeve coated with cotton. The paper sleeve with the sample was plugged by cotton. The preparation was dried in an oven at a temperature of no more than $80^{\circ} \mathrm{C}$ for about one hour, and then it was inserted into a soxhlet device which had been linked to a fat pumpkin containing dried boiling stones and weight. The preparation was extracted with hexane or other fat solvents for approximately 6 hours.

The hexane was refined and the fat extract was dried in the drying oven at $105^{\circ} \mathrm{C}$. The fat extract was refrigerated and weighed. This drying was repeated until a fixed weight was reached. Meat fat percentage was calculated by using the following formula:

$\%$ fat $=[$ (sample weight $(\mathrm{g})$ - fat weight before extraction

(g)) / fat weight after extraction (g)] x 100\%

Meat MDA. MDA concentration were measured using the method of Rice-Evans et al. (1991) with Thiobarbituric Acid Reactive Substances (TBARS). The analysis procedure was: chicken meat was made by dissolving $1 \mathrm{~g}$ of chicken meat that had been fixed into 2 $\mathrm{mL}$ PBS acetate in an Eppendorf tube then centrifuged for 20 minutes at a speed of $10,000 \mathrm{rpm}$. MDA reagent was made by mixing $750 \mu \mathrm{L}$ phosphoric acid with $50 \mu \mathrm{L}$ TEP (Tetra Ethoxypropane) into a $13 \mathrm{~mL}$ polypropylene tube, then the mixture was shaken until homogeneous and added $250 \mu \mathrm{L}$ TBA (Trichlorobarbituric acid). A total of $450 \mu \mathrm{L}$ of distilled water was then added to the mixture. The mixture was taken as much as $2 \mathrm{~mL}$ and then mixed into the sample. The sample was incubated at $80{ }^{\circ} \mathrm{C}$ for 1 hour and cooled, then centrifuged at a speed of 3,000 rpm for 5 minutes to take the supernatant. The supernatant was then measured for 7 absorbances with a spectrophotometer at the maximum wave length $(\max \lambda=532 \mathrm{~nm})$.

Meat fatty acids. Meat fatty acid was measured by using methylation method (AOAC,1984). Fine and homogeneous meat samples were weighed around 20-30 $\mathrm{mg}$ and inserted into Teflon-covered tubes. One 
milliliter of $0.5 \mathrm{~N} \mathrm{NaOH}$ was mixed in methanol and the mixture was heated in a water bath for 20 minutes (hydrolysis stage) then $2 \mathrm{~mL}$ of BF3 (baron trifluoride methanol) $16 \%$ was added as a catalyst and $5 \mathrm{mg} / \mathrm{mL}$ internal standard, then the mixture was reheated for 20 minutes. After getting colder, $2 \mathrm{~mL}$ of saturated $\mathrm{NaCl}$ and $1 \mathrm{~mL}$ of hexane were added and the mixture was shaken well. The hexane layer was removed with the help of the dropper pipette into a tube containing $0.1 \mathrm{~g}$ of $\mathrm{Na}_{2} \mathrm{SO}_{4}$ anhydrous, and left for 15 minutes. The liquid phase was separated and injected into a gas chromatography as much as $1 \mu \mathrm{L}$ using the capillary column, cyanoprophil meth, $6 \mathrm{~m}$ column length, $0.25 \mathrm{~mm}$ inner diameter, $200^{\circ} \mathrm{C}$ injection temperature, $190^{\circ} \mathrm{C}$ initial column temperature, and $230^{\circ} \mathrm{C}$ final column temperature. For standard internal methods, the number of each component in the sample was calculated using the following formula:

$$
C_{x}=\left(A_{x} \times R \times C_{s}\right) / A_{s}
$$

where: Cx is concentration of component $\mathrm{x}, \mathrm{Cs}$ is internal standard concentration, $\mathrm{Ax}$ is peak area of component $\mathrm{x}$, As is the peak area of the internal standard, and $\mathrm{R}$ is the detector response to component $\mathrm{x}$ is relative to the standard

\section{Data Analysis}

Data were analyzed using ANOVA and if there were significant differences, the data were analyzed further using Duncan's Multiple Distance Test (Steel \& Torrie, 1995). MDA concentration and fatty acids were analyzed using descriptive statistics.

\section{RESULTS}

Performances of kampong chicken fed the experimental diets are presented in Table 2. Supplementation of NLSM in the diet of kampong chicken did not significantly affect feed consumption, body weight gain, feed conversion, and mortality.

The average effects of using NLSM in rations on the lipids contents of kampong-chicken meats during the study (4-12 weeks) are shown in Table 3. The results showed that the addition of $0.5 \%-2.5 \%$ NLSM in the ra-

Table 2. Performance of kampong chicken given noni leaf shoot meal (NLSM) at the age of 4 to 12 weeks

\begin{tabular}{ccccc}
\hline & \multicolumn{4}{c}{ Variables } \\
\cline { 2 - 5 } Treatments & $\begin{array}{c}\text { Feed } \\
\text { consumption } \\
\text { (g/chick) }\end{array}$ & $\begin{array}{c}\text { Weight gain } \\
\text { (g/chick) }\end{array}$ & $\begin{array}{c}\text { Feed } \\
\text { conversion }\end{array}$ & $\begin{array}{c}\text { Mortality } \\
(\%)\end{array}$ \\
\hline R0 & $3231.45 \pm 3.38$ & $975.30 \pm 17.02$ & $3.31 \pm 0.06$ & 0 \\
R1 & $3234.10 \pm 4.40$ & $947.30 \pm 33.59$ & $3.42 \pm 0.13$ & 0 \\
R2 & $3234.35 \pm 6.04$ & $979.30 \pm 44.40$ & $3.31 \pm 0.15$ & 0 \\
R3 & $3239.50 \pm 7.00$ & $937.50 \pm 10.52$ & $3.46 \pm 0.38$ & 0 \\
R4 & $3237.20 \pm 6.62$ & $947.70 \pm 77.41$ & $3.44 \pm 0.28$ & 0 \\
R5 & $3242.30 \pm 12.82$ & $944.40 \pm 48.24$ & $3.44 \pm 0.18$ & 0 \\
\hline
\end{tabular}

Note: $\mathrm{R} 0=$ control ration; $\mathrm{R} 1=0.5 \%$ NLSM in ration; $\mathrm{R} 2=1 \%$ NLSM in ration; $\mathrm{R} 3=1.5 \%$ NLSM in ration; $\mathrm{R} 4=2 \%$ NLSM in ration, and $\mathrm{R} 5=$ $2.5 \%$ NLSM in ration. tion significantly reduced $(\mathrm{p}<0.05)$ cholesterol and LDL contents of kampong-chicken meats. However, NLSM addition in the ration did not have a significant effect on HDL contents of kampong-chicken meats.

The average effects of using NLSM in the rations on the MDA contents of kampong-chicken meat during the study (ages 4-12 weeks) are shown in Table 4. As shown in Table 4, the MDA concentrations in the meats of kampong chickens decreased due to the presence of flavonoids and $\beta$-carotene having antioxidant activities.

The results in Table 5 showed that the compositions of unsaturated fatty acids in the meats of kampong chickens fed diet added with different doses of NLSM were higher compared to the compositions of saturated fatty acids. The decrease followed the decrease in saturated fatty acids contents of kampong-chicken meat in the value of the fat contents. There were also other minors/trace compounds during this study.

\section{DISCUSSION}

\section{Performances of Kampong Chicken}

The averages feed consumptions during the experiment varied from $3231.45 \pm 3.38 \mathrm{~g} / \mathrm{chick}$ (R0) to $3242.30 \pm 12.82 \mathrm{~g} / \mathrm{chick}$ (R4) with the weight gains ranges of $937.50 \pm 10.52 \mathrm{~g} / \mathrm{chick}$ (R3) to $975.30 \pm 17.02 \mathrm{~g} / \mathrm{chick}$ (R0), and feed conversions varied from $3.3 \pm 0.06$ (R0) to $3.46 \pm 0.38$ (R3). These results were consistent with the results of the study by Wardiny et al. (2011) that the use of $1 \%-3 \%$ of noni leaf meal in broilers did not give a sig-

Table 3. Cholesterol, HDL, and LDL content of kampongchicken meat at 12 weeks of age $(\mathrm{mg} / 100 \mathrm{~g})$

\begin{tabular}{cccc}
\hline \multirow{2}{*}{ Treatments } & \multicolumn{3}{c}{ Component } \\
\cline { 2 - 4 } & Cholesterol & HDL & LDL \\
\hline R0 & $90.91 \pm 24.86^{\mathrm{b}}$ & $5.16 \pm 1.49$ & $42.35 \pm 10.36^{\mathrm{c}}$ \\
R1 & $57.04 \pm 7.42^{\mathrm{a}}$ & $3.67 \pm 0.23$ & $31.01 \pm 5.97^{\mathrm{bc}}$ \\
R2 & $59.26 \pm 15.50^{\mathrm{a}}$ & $3.72 \pm 0.59$ & $25.17 \pm 9.29^{\mathrm{b}}$ \\
R3 & $39.70 \pm 2.42^{\mathrm{a}}$ & $4.08 \pm 0.16$ & $22.06 \pm 0.55^{\mathrm{ab}}$ \\
R4 & $60.38 \pm 10.19^{\mathrm{a}}$ & $3.91 \pm 0.20$ & $22.45 \pm 7.26^{\mathrm{ab}}$ \\
R5 & $54.69 \pm 9.04^{\mathrm{a}}$ & $4.39 \pm 0.59$ & $11.49 \pm 10.99^{\mathrm{a}}$ \\
\hline
\end{tabular}

Note: Means in the same column with different superscripts differ significantly $(\mathrm{p}<0.05) \mathrm{R} 0=$ control ration; $\mathrm{R} 1=0.5 \%$ NLSM in ration; $\mathrm{R} 2=1 \%$ NLSM in ration; R3 $=1.5 \%$ NLSM in ration; $\mathrm{R} 4=2 \% \mathrm{NLSM}$ in ration, and $\mathrm{R} 5=2.5 \% \mathrm{NLSM}$ in ration.

Table 4. MDA content of kampong-chicken meat at 12 weeks of age

\begin{tabular}{ccc}
\hline Treatments & MDA $(\mu \mathrm{g} / \mathrm{g})$ & Decreased MDA $(\%)$ \\
\hline R0 & 1.84 & - \\
R1 & 1.72 & 6.52 \\
R2 & 1.76 & 4.35 \\
R3 & 1.10 & 40.22 \\
R4 & 1.20 & 34.78 \\
R5 & 1.05 & 42.93 \\
\hline
\end{tabular}

Note: $\mathrm{R} 0=$ control ration; $\mathrm{R} 1=0.5 \%$ NLSM in ration; $\mathrm{R} 2=1 \% \mathrm{NLSM}$ in ration; $\mathrm{R} 3=1.5 \%$ NLSM in ration; $4=2 \%$ NLSM in ration, and R5= $2.5 \%$ NLSM in ration. 
Table 5. Composition of fat, saturated fatty acids, and unsaturated fatty acids of kampong-chicken meat at 12 weeks of age

\begin{tabular}{|c|c|c|c|c|c|c|}
\hline \multirow{2}{*}{ Variables } & \multicolumn{6}{|c|}{ Treatments } \\
\hline & R0 & R1 & R2 & R3 & R4 & R5 \\
\hline Fat (\%) & 5.77 & 4.14 & 4.09 & 3.51 & 4.31 & 4.5 \\
\hline \multicolumn{7}{|l|}{ Saturated fatty acids (SFA) (\%) } \\
\hline Lauric acid & 0.05 & 0.05 & 0.03 & 0.04 & 0.06 & 0.06 \\
\hline Myristic acid & 0.56 & 0.53 & 0.52 & 0.44 & 0.52 & 0.55 \\
\hline Pentadecanoic acid, & 0.08 & 0.08 & 0.09 & 0.09 & 0.10 & 0.09 \\
\hline Palmitic acid & 22.65 & 21.85 & 21.54 & 19.41 & 21.27 & 21.59 \\
\hline Heptadecanoic acid, & 0.13 & 0.14 & 0.17 & 0.18 & 0.19 & 0.16 \\
\hline Stearic acid & 5.49 & 5.8 & 6.61 & 5.59 & 5.91 & 5.41 \\
\hline Arachidic acid & 0.10 & 0.13 & 0.14 & 0.13 & 0.14 & 0.12 \\
\hline Behenic acid & 0.05 & 0.05 & 0.06 & 0.06 & 0.06 & 0.04 \\
\hline Lignoceric acid & 0.03 & 0.04 & 0.03 & 0.04 & 0.03 & 0.03 \\
\hline \multicolumn{7}{|l|}{ Unsaturated fatty acid (UFA) (\%) } \\
\hline Myristoleic acid & 0.12 & 0.12 & 0.09 & 0.08 & 0.09 & 0.12 \\
\hline Palmitoleic acid & 4.11 & 3.90 & 2.90 & 2.51 & 2.86 & 3.90 \\
\hline Heptadecanoic acid & 0.08 & 0.08 & 0.08 & 0.08 & 0.09 & 0.08 \\
\hline Eicosenoic acid, & 0.24 & 0.19 & 0.19 & 0.20 & 0.20 & 0.17 \\
\hline Nervonic acid & 0.02 & 0.03 & 0.02 & 0.02 & 0.02 & 0.02 \\
\hline Eicosedienoic acid & 0.18 & 0.18 & 0.19 & 0.17 & 0.18 & 0.18 \\
\hline Linolenic acid & 0.55 & 0.54 & 0.63 & 0.52 & 0.67 & 0.67 \\
\hline Eicosapentaenoic acid, (EPA) & 0.04 & 0.04 & 0.03 & 0.04 & 0.03 & 0.03 \\
\hline Docosahexaenoic acid, (DHA) & 0.09 & 0.12 & 0.14 & 0.11 & 0.15 & 0.15 \\
\hline Linoleic acid & 17.55 & 17.5 & 20.71 & 21.58 & 20.37 & 19.01 \\
\hline g-Linolenic acid & 0.10 & 0.10 & 0.11 & 0.09 & 0.09 & 0.11 \\
\hline Eicosetrienoic acid, & 0.14 & 0.15 & 0.15 & 0.12 & 0.15 & 0.14 \\
\hline Arachidonic acid, & 0.72 & 0.99 & 1.03 & 0.89 & 0.99 & 1.00 \\
\hline Elaidic acid & 0.17 & 0.22 & 0.17 & 0.15 & 0.17 & 0.17 \\
\hline Oleic acid & 32.23 & 33.04 & 32.94 & 33.48 & 31.7 & 32.78 \\
\hline Rasio SFA: UFA & $1: 1.93$ & $1: 2.00$ & $1: 2.03$ & $1: 2.31$ & $1: 2.04$ & $1: 2.09$ \\
\hline
\end{tabular}

Note: $\mathrm{R} 0=$ control ration; $\mathrm{R} 1=0.5 \%$ NLSM in ration; $\mathrm{R} 2=1 \%$ NLSM in ration; $\mathrm{R} 3=1.5 \%$ NLSM in ration; $\mathrm{R} 4=2 \%$ NLSM in ration, and $\mathrm{R} 5=2.5 \%$ NLSM in ration. There was also other minors/trace compounds during this study.

nificant effect on feed consumption. Also, Syahruddin et al. (2011) reported that the provision of fermented noni leaf flour at the levels of $3 \%-21 \%$ in broiler rations did not have a significant effect on performances of broilers. The body weight gains found in the present experiment were higher than those reported in 12-week crossbred kampung and Pelung-kampung chickens (923.57 g/ chick) and the ration conversion was not much different, i.e. 3.39 (Gunawan \& Sartika, 2001).

This study found that the absence of differences in feed consumptions of kampong chicken was caused by the same palatabilities of all treatment rations. The chemical analysis showed that NLSM contained 0.03\% tannin and $0.26 \%$ saponin. The tannin content in the treatment rations during the study was $0.969 \mathrm{~g}$ in $\mathrm{R} 1$; $0.970 \mathrm{~g}$ in R2; $0.972 \mathrm{~g}$ in R3; $0.971 \mathrm{~g}$ in R4; and $0.973 \mathrm{~g}$ in R5. The saponin contents of the experimental rations were $8.41 \mathrm{~g}$ in $\mathrm{R} 1 ; 8.41 \mathrm{~g}$ in $\mathrm{R} 2 ; 8.42 \mathrm{~g}$ in R3; $8.42 \mathrm{~g}$ in R4; and $8.43 \mathrm{~g}$ in R5. The tolerance limit of tannin content in chicken rations is $2.6 \mathrm{~g} / \mathrm{kg}$ (Kumar et al., 2005). The contents of tannins and saponins in the present study were very low, so the supplementation of NLSM in the ration did not affect palatability. The nonsignificant differences in feed consumption were also due to the similar com- positions of the rations fed to the experimental chickens that eventually had relatively similar ration palatability that did not affect the appetites of experimental chickens.

The body weights of kampong chickens during the study were ranged from 937.50-979.30 g/chick. This small range was presumably caused by the quality and quantity of rations consumed were similar. The use of NLSM in the ration did not affect the function of the body organs of kampong chickens that eventually developed and produced the same weight gains. The body-weight gains found in the present study were better than those reported in the performance of PelungKampung and Kampung-crossing chickens for 12 weeks (898.10 g/chick) (Gunawan \& Sartika, 2001).

The feed conversion ratio of kampong chicken during the study was 3.31-3.46. There was no difference in the conversion of ration during the study. This result might be due to the similar feed consumption and body weight gain. These results were in line with those reported by Syahruddin et al. (2011).

Mortality is a crucial factor for the success of chicken farming. During the experiment, there was no mortality of experimental chickens observed in the pres- 
ent study. This result indicated that NLSM were safe to be use as an alternative feed ingredient in compiling especially chicken rations. This condition can be caused by the presences of tannins and saponins that can be eliminated by the drying process.

\section{Lipid Contents of Kampong-Chicken Meat}

Supplementation of $1.5 \%$ NLSM in the ration reduced meat cholesterol by $56.33 \%(90.91 \pm 24.86 \mathrm{mg} / 100 \mathrm{~g}$ to $39.70 \pm 2.42 \mathrm{mg} / 100 \mathrm{~g})$. The present result was in accordance with the report of Syahruddin et al. (2011) that the use of $21 \%$ noni leaf meal significantly reduced meat cholesterol levels of broiler chickens as much as $56.96 \%$. The decreased meat cholesterol caused by $\beta$-carotene was found in NLSM. Based on chemical analysis, the $\beta$-carotene content of NSLM was $180 \mathrm{mg} / \mathrm{kg}$. $\beta$-carotene has an antioxidant activity that will gobble free radicals that lead to the increased activity of the lipoprotein-lipase enzyme. The lipoprotein-lipase enzyme is activated by the apoliprotein $C$ that hydrolizes triglycerides into fatty acids and glyserol. The hydrolyzing of triglycerides causes a decrease in the plasma triglyceride concentrations. The antioxidant activity of $\beta$-carotene also protects the omega-3 fatty acids. Omega- 3 fatty acids comprising $60 \%$ long-chain fatty acids omega-3 (EPA and DHA) are susceptible to lipid oxidation (Schreiber et al., 2013).

Amirshekari et al. (2016) state that the inhibition of the enzyme system involved in the synthesis of cholesterol causes a decrease in cholesterol absorption in the intestine. The decreased plasma cholesterol causes a reduction in cholesterol concentrations in livestock products, both eggs and meat. The high content of $\beta$-carotene in feedstuffs consumed will lower the cholesterol contents of chicken meats (Lee et al., 2010; Syahruddin et al., 2011; Santi et al., 2015). Also, the presence of antioxidant activity can inhibit and prevent the occurrence of lipid peroxidation in the plasma that eventually reduces cholesterol and inhibits cell damage (Laudadio et al., 2014; Karppi et al., 2013; Shahidi \& Zhong, 2015). The reduced levels of cholesterol resulted in the decreased transport of cholesterol to the tissues that eventually reduces the fat content of meat.

\section{MDA Content of Kampong-Chicken Meat}

The use of noni ( $M$. citrifolia) leaf shoot meal (NLSM) in the diet decreased malondialdehyde (MDA) concentration as compared with the control diet. MDA concentration reduced by $42.93 \%$ from $1.84 \mu \mathrm{g} / \mathrm{g}$ (R0) to $1.05 \mu \mathrm{g} / \mathrm{g}$ (R5) with the presences of flavonoids, vitamin $A$, and $\beta$-carotene in noni (M. citrifolia) leaf shoot meal as natural antioxidants. The present result was in accordance with the report of Palupi et al. (2014) and Santi et al. (2015) ) that feeding of I. zollingeriana top leaf meal in laying hens and broiler increased antioxidant contents of the egg and decreased MDA concentration of the meat. The increased egg antioxidant and decreased meat MDA concentration were caused by $\beta$-carotene content of $I$. zoolingeriana. $\beta$-carotene is a natural antioxidant having essential roles in reducing free radical chain re- actions in tissue and inhibiting lipid oxidation (Shahidi, 2009; Tavares et al., 2011; Kim et al., 2013; Surai et al., 2016).

Yeum et al. (2009) reported the role of $\beta$-carotene against oxidation and Zheng et al. (2009) stated that phenolic compounds had high activity to reduce free radicals production. In addition, antioxidant supplements improve breast-meat quality of broiler chickens (Tavarez et al., 2011) and reduce the MDA contents of egg yolk (Akdemir et al., 2009). In addition, dietary antioxidants increase the tenderness of meat and reduce lipid oxidation in broiler breast and thigh (Delles et al., 2014).

One of the most commonly used indicators of lipid peroxidation related to oxidative stress is Malondialdehyde (Aksu et al., 2010). According Chen et al. (2009), MDA can be used as an indicator of antioxidant activity. Antioxidant acts as a deterrent to the occurrence of lipid peroxidation because antioxidants can stabilize free radicals so that they are not harmful to the body (Kurkcu, 2010). The lower MDA concentration in the meats of free-range chicken indicates that the meat of kampong chicken contains high antioxidants.

\section{Fatty Acid Composition}

Based on this study, the compositions of unsaturated fatty acids in the meats of kampong chicken fed rations supplemented with NLSM were higher compared to those of saturated fatty acids. The results showed the highest variation in the ratio of saturated and unsaturated fatty acids in treatment $\mathrm{R} 4$ with a value of 1: 2.31 and the lowest ratio in the control treatment R0 with a value of 1: 1.93. This decrease was also followed by a lower in the the fat contents of the meat. The mechanism of decreasing fat content and increasing unsaturated fatty acid content of meat is related to the interaction of $\beta$-carotene contained in the rations $\mathrm{R} 1$ to R5. According to Velasco et al. (2011), plant extracts are natural antioxidants that are outstanding effects on improving meat quality because they inhibit or slow down the lipid oxidation and microbial growth. Fassah (2012) also explains that the addition of natural antioxidants can reduce MDA and total SFA (Saturated Fatty Acids) and increase PUFA (Poly Unsaturated Fatty Acids) contents of meat that eventually increase the stability of meat oxidation that finally will improve the meat quality. According to Shahzad et al. (2011) poultry meat and eggs, as high-quality animal proteins, are important sources for sustaining health and nutrition of human beings. Furthermore, Muhlisin et al. (2016) confirm that the dark meat of poultry exhibited higher antioxidant enzyme activity and contained more iron than white meat. Also, Choi et al. (2016) state that fat plays an essential role in the stability of meat emulsions, increasing water capacity, and the essential level of meat hardness. The decreased fat contents in poultry products, especially meat, will produce products that are safe for health.

\section{CONCLUSION}

Feeding 2.5\% noni leaf shoot meal in kampong chicken produces the same performances as the control, 
but reduces the cholesterol, LDL, MDA, saturated fatty acids and increases unsaturated fatty acids content of kampong-chicken meat.

\section{CONFLICT OF INTEREST}

The authors declare that there is no conflict of interest with any financial support, personal, or relationships with other people or organization related to the material used and discussed in the manuscript.

\section{REFERENCES}

Akdemir F. \& K. Sahin. 2009. Genistein supplementation to the quail: effects on egg production and egg yolk genistein, daidzein, and lipid peroxidation levels. Poult. Sci. 88: 21252131. https://doi.org/10.3382/ps.2009-00004

Aksu, D. S., T. Aksu, B. Ozsoy, \& E. Baytok. 2010. The effects of replacing inorganic with a lower level of organically complexed minerals $(\mathrm{Cu}, \mathrm{Zn}$ and $\mathrm{Mn})$ in broiler diets on lipid peroxidation and antioxidant defense systems. Asian-Australas. J. Anim. Sci. 23:1066-1072. https://doi. org/10.5713/ajas.2010.90534

Amirshekari T., N. Ziaei, S.M. Ghoreishi, \& E. Esfandiaspur. 2015. The effects of adding aqueous extract and dried aerial part powder of Tribulus terrestris on productive performance and blood parameters of laying hens. J. Appl. Poult. Res. 25: 145-155. https://doi.org/10.3382/japr/pfv07

AOAC (Association of Analytical Chemists). 1984. Standard Official Methods of Analysis of the Association of Analytical Chemists. 14th Edition, S.W Williams, Washington DC.

Burke, R., B. Diamondstone, R.Velapoldi, \& O. Menis. 1974. Mechanisms of the Liebermann-Burchard and Zak color reactions for cholesterol. Clinical Chemistr, 20: 794-801.

Chen, P., A.Q. Wang, \& A.S. Shan. 2009. Effects of Ligustrum lucidum fruits on growth performance, antioxidation and meat quality in Arbor Acres broilers. AsianAustralas. J. Anim. Sci. 22: 700-705. https://doi.org/10.5713/ ajas.2009.80537

Choi, Y.S., J.H. Choi, D.J. Han, H.Y. Kim, M.A. Lee, J.Y. Jeong, H.J. Chung, \& C. Kim. 2010. Effect of replacing pork back fat with vegetable oils and rice bran fiber on the quality of reduced fat frankfurters. Meat Sci. 84:557-563. https://doi. org/10.1016/j.meatsci.2009.10.012

Delles, R.M., Y.L. Xiong, A.D. Treu, T.Ao, \& K.A. Dawson. 2014. Dietary antioxidant supplementation enhances lipid and protein oxidative stability of chicken broiler meat through promotion of antioxidant enzym activity. Poult. Sci. 93: 1561-1570. https://doi.org/10.3382/ps.2013-03682

Dhama K, S.K. Latheef, S. Mani, H.A. Samad, K. Karthik, R. Tiwari, R.U. Khan, M. Alagawany, M.R. Farag, G.M. Alam, V. Laudadio, \& V. Tufarelli. 2015. Multiple beneficial applications and modes of action of herbs in poultry health and production-A review. Int. J. Pharmacol. 11: 152176. https://doi.org/10.3923/ijp.2015.152.176

Doss, A, M. Pugalenthi, D. Rajendrakumaran, \& V. Vadivel. 2010. Phenols, flavonoids and antioxidant activity of underutilized legume seeds. Asian J. Exp. Biol. Sci. 1:700-705.

Fassah, D. M. 2012. Efek pemberian ekstrak limbah teh hitam sebagai sumber antioksidan dal level energi-protein pakan yang berbeda terhadap stabilitas oksidatif dan kualitas daging ayam broiler. Buletin Peternakan 36: 75-86. https:// doi.org/10.21059/buletinpeternak.v36i2.1583

Ferretti, G., T. Bacchetti, A. Belleggia, \& D. Neri. 2010. Cherry antioxidants: from farm to table. Molecules 15: 6993-7005. https://doi.org/10.3390/molecules15106993

Gunawan, B., \& T. Sartika. 2001. Persilangan ayam pelung jan$\tan x$ kampung betina hasil seleksi generasi kedua (G2).
Jurnal Ilmu Ternak dan Veteriner 6: 21-27.

Hoenselaar, R. 2012. Saturated fat and cardiovascular disease: the discrepancy between the scientific literature and dietary advice. Nutrition 28: 118-123. https://doi. org/10.1016/j.nut.2011.08.017

Karppi, J, S.Kurl, K. Ronkainen, J. Kauhanen, \& J.A. Laukkanen . 2013. Serum carotenoids reduce progression of early atherosclerosis in the carotid artery wall among eastern Finnish men. PLoS ONE 8: e64107. https://doi. org/10.1371/journal.pone.0064107

Kim, I.S., S.K.Jin, M.R. Yang, G.M, Chu, J.H. Park, R.H.I. Rashid, J.Y. Kim, \& S.N. Kang. 2013. Efficacy of tomato powder as antioxidant in cooked pork patties. AsianAustralas. J. Anim. Sci. 26: 1339-1346. https://doi. org/10.5713/ajas.2013.13079

Kumar, R. S., T. Sivakumar, R. S. Sunderam, M. Gupta, U. K. Mazumdar, P. Gomathi, Y. Rajeshwar, S. Saravanan, M. S. Kumar, K. Murugesh, \& K. A. Kumar. 2005. Antioxidant and antimicrobial activities of Bauhinia racemosa L. stem bark. Braz. J. Med. Biol. Res. 38: 1015-1024. https://doi. org/10.1590/S0100-879X2005000700004

Kurkcu, R. 2010. The effects of short-term exercise onthe parameters of oxidant and antioxidant system in handball players. African J. Pharm. Pharmacol. 4: 448-452.

Laudadio, V., E Ceci, N.M.B Lastella, M. Introna, \& V. Tufarelli. 2014. Low-fiber alfalfa (Medicago sativa L.) meal in the laying hen diet: Effects on productive traits and egg quality. Poult. Sci. 93: 1868-1874. https://doi.org/10.3382/ ps.2013-03831

Lee, C.X., B. D, Lee, J.C. Na, \& G. An. 2010, Carotenoid accumulation and their antioxidant activity in spent laying hens as affected by polarity and feeding period. AsianAust. J. Anim. Sci. 23:799-805. https://doi.org/10.5713/ ajas.2010.90296

Leeson, S. \& J. D. Summers. 2009. Commercial Poultry Nutrition. Nottingham University Press. https://doi. org/10.7313/UPO9781904761099

Muhlisin, D.T.U., J.H. Lee, J.H. Cho, \& S.K. Lee. 2016. Antioxidant enzyme activity, iron content and lipid oxidation of row and cooked of Korean native chickens and other poultry. Asian-Australas. J. Anim. Sci. 29: 695-701. https://doi.org/10.5713/ajas.15.0256

National Standardization Agency of Indonesia. 1992. Food and Beverages, Test Methods. SNI 01-2891-1992. pp. 16-17.

Palupi, R., L. Abdullah, D. A. Astuti, \& Sumiati. 2014. High antioxidant egg production through substitution of soybean meal by Indigofera sp top leaf meal in laying hen diets. Int. J. Poult. Sci. 13: 198-203. https://doi.org/10.3923/ ijps.2014.198.203

Phan-Thi, H., \& Y. Wache. 2014. Isomerization and increase in the antioxidant properties of lycopene from Momordica cochinchinensis (gac) by moderate heat treatment with UVVis spectra as a marker. Food Chem. 156:58-63. https://doi. org/10.1016/j.foodchem.2014.01.040

Phan-Thi, H. P. Durand, M. Prost, E. Prost, \& P. Wache. 2016. Effect of heat-processing on the antioxidant and prooxidant activities of $\beta$-carotene from natural and synthetic origins on red blood cells. Food Chem. 190: 1137-1144, https://doi.org/10.1016/j.foodchem.2015.06.088

Rice-Evans, C., A.T. Diplock, \& M.C.R. Symons. 1991. Techniques in Free Radical Research. Elsevier Science Pub. Co. Pp: 146-202.

Santi, M.A., Sumiati, \& L. Abdullah. 2015. Cholesterol and malondialdehyde contents of broiler-chicken meat supplemented with Indigofera zolingeriana top leaf meal. Med. Pet. 38:163-168. https://doi.org/10.5398/ medpet.2015.38.3.163

Schreiber, S. B., J. J. Bozell, D. G. Hayes, \& S. Zivanovic. 2013. Introduction of primary antioxidant activity to chitosan 
for application as a multifunctional food packaging material. Food Hydrocoll. 33: 207-214. https://doi.org/10.1016/j. foodhyd.2013.03.006

Shahidi, F. 2009. Nutraceuticals and functional foods:whole versus processed foods. Trends Food Sci. Technol. 20: 376387. https://doi.org/10.1016/j.tifs.2008.08.004

Shahidi F. \& Y. Zhong. 2015. Measurement of antioxidant activity. J. Func. Foods. 18:757-781. https://doi.org/10.1016/j. jff.2015.01.047

Shahzad M., F. Rizvi, A. Khan, M. Siddique, M.Z. Khan, \& M.Z. Khan. 2011. Diagnosis of Avian Paramyxovirus type1 infection in chicken by immunoflourescence technique. Int. J. Agric. Biol. 13:266-270.

Steel, R. \& J. Torrie. 1995. Prinsip dan Prosedur Statistika. Alih bahasa: Sumantri B. Edisi ke-2. Gramedia Pustaka Utama, Jakarta.

Sunder, J., D.R. Sing, A. Kundu, \& S. Jeyakumar. 2011. Effect of feeding Morinda citrifolia extract on blood biochemical profile of Nicobari fowl and broiler. Anim. Sci. Report. 5: 141-146.

Surai P.F., I.F. Vladimir, \& K. Filiz. 2016. Antioxidant systems in chick embryo development. Part 1. Vitamin E, carotenoids and selenium. Anim. Nutr. 2: 1-11. https://doi. org/10.1016/j.aninu.2016.01.001
Syahruddin, E., H. Abbas, E. Purwati, \& Y. Heryandi. 2011. Effect of fermented noni leaf (Morinda citrifolia L.) in diets on cholesterol content of broiler chicken carcass. Jurnal Ilmu Ternak dan Veteriner 16: 266-271.

Tavarez, M.A., D.D. Boler, K.N. Bess, J. Zhao, F.Yan, A.C. Dilger, F.K. McKeith, \& J. Killefer. 2011. Effect of antioxidant and oil quality on broiler performance, meat quality and lipid oxidation. Poult. Sci. 90: 922-930. https://doi. org/10.3382/ps.2010-01180

Velasco, V. \& P. Williams. 2011. Improving meat quality through natural antioxidants. Chilean journal of Agricultural Research 71: 313-318. https://doi.org/10.4067/ S0718-58392011000200017

Wardiny, T. M., T. E. A. Sinar, \& D. Zainuddin. 2011. Substitusi tepung daun mengkudu dalam ransum meningkatkan kinerja ayam broiler. Jurnal Matematika Sains dan Teknologi 12: 92-100.

Yeum, K.J., G. Beretta, N. I. Krinsky, R. M. Russell, \& G. Aldini. 2009. Synergistic interactions of antioxidant nutrients in a biological model system. Nutrition 25: 839-846. https://doi.org/10.1016/j.nut.2009.01.011

Zheng, G., L. Xu, P.Wu, H. Xie, Y. Jiang, F. Chen, \& X. Wei. 2009. Polyphenols from longan seeds and their radicalscavenging activity. Food Chem. 116: 433-436. https://doi. org/10.1016/j.foodchem.2009.02.059 